\title{
ANALISIS EFISIENSI BIAYA PERBANDINGAN METODE LCL DAN KONSOLIDASI PADA PROSES IMPOR KOMPONEN PT CATERPILLAR INDONESIA DARI CHINA DAN JEPANG
}

\author{
Achsanul Nashir \\ Institut Ilmu Sosial dan Manajemen STIAMI \\ nashirachsanul@gmail.com
}

\begin{abstract}
Abstrak. Menghadapi era perdagangan bebas, pemerintah dan dunia usaha harus terus meningkatkan pertumbuhan di seluruh sektor seperti perdagangan, investasi, dan sebagainya. Daya saing ekonomi Indonesia secara global pada 2013 naik tiga peringkat dibandingkan dengan tahun sebelumnya. Ini pula yang terjadi pada pasar alat berat, khususnya PT Caterpillar Indonesia. PT Caterpillar Indonesia sedang menghadapi persaingan yang semakin ketat dengan produsen alat-alat berat lainnya, baik dari dalam negeri maupun dari luar negeri.

Dalam penelitian ini akan membahas trucking, storage, freight, dan duty yang dilakukan PT Caterpillar Indonesia dalam rangka penghematan dan efisiensi biaya. Pendekatan yang digunakan adalah penelitian deskriptif kualitatif. Penulis juga ingin mengangkat fenomena dan hambatanhambatan yang ada dalam penerapan sistem manajemen, berusaha mencari pembahasan tentang permasalahan yang ada serta menjabarkan secara deskriptif hasil penelitian yang telah dicapai.

Data menunjukkan bahwa ada perbedaan efisiensi biaya rata-rata storage dibandingkan metode konsolidasi metode LCL sebesar $40.35 \%$. Untuk perbedaan efisiensi biaya rata-rata trucking dibandingkan metode konsolidasi metode LCL sebesar 24\%. Sementara itu tidak ada perbedaan efisiensi biaya rata-rata freight dibandingkan metode konsolidasi LCL. Terakhir ada perbedaan efisiensi biaya rata-rata keseluruhan dibandingkan metode konsolidasi dengan metode LCL sebesar $15.62 \%$.
\end{abstract}

Kata Kunci : Efisiensi Biaya, Metode LCL

Abstract. Facing an era of free trade, governments and businesses must continue to increase growth across sectors such as trade, investment, and so forth. Indonesia's economic competitiveness globally in 2013 rose three ratings compared to the previous year. This is also the case in the heavy equipment market, especially PT Caterpillar Indonesia. PT Caterpillar Indonesia is facing increasingly tight competition with other heavy equipment manufacturers, both from domestic and abroad.

In this research will discuss trucking, storage, freight, and duty by PT Caterpillar Indonesia in order to save and cost efficiency. The approach used is descriptive qualitative research. The authors also want to lift the phenomenon and obstacles that exist in the implementation of management systems, trying to find a discussion of existing problems and describe the descriptive research results that have been achieved.

The data shows that there is a difference in the average cost efficiency of storage compared to LCL method consolidation method by 40.35\%. For the difference in average cost efficiency of trucking compared to LCL method consolidation method by 24\%. While there is no difference in the average cost efficiency of freight over the LCL consolidation method. Finally there is an overall average cost efficiency difference compared to consolidation method with LCL method of $15.62 \%$.

Keywords : Cost Efficiency, LCL Method

\section{PENDAHULUAN}

Menghadapi era perdagangan bebas Asia Tenggara dalam kerangka Masyarakat 
Ekonomi ASEAN (MEA) 2015, pemerintah dan dunia usaha harus terus meningkatkan pertumbuhan di seluruh sektor, seperti perdagangan, investasi, dan sebagainya. Daya saing ekonomi Indonesia secara global pada 2013 naik tiga peringkat dibandingkan dengan tahun sebelumnya. Menurut laporan Institute for Management Development (IMD), Indonesia berada di posisi 39 dalam daftar World Competitiveness Rangking's 2013. Tahun lalu peringkat Indonesia berada di urutan 42. Meski mengalami peningkatan peringkat, Indonesia masih di bawah negaranegara ASEAN lain, Filipina misalnya yang tepat di atas Indonesia (urutan 38). Semua perusahaan dalam menghadapi persaingan pasar, memerlukan kemampuan dalam pengelolaan sumber daya perusahaan secara efisien dan efektif agar dapat memberikan hasil maksimal bagi kemajuan perusahaan. Artinya, permintaan akan kebutuhan alat-alat berat sekarang ini berkembang dengan sangat pesat.

Persaingan pada pasar alat berat yang sangat ketat memberikan pengaruh yang sangat besar bagi industri alat-alat berat khususnya bagi PT Caterpillar Indonesia. Pemenuhan permintaan pasar yang belum bisa dipenuhi oleh PT Caterpillar Indonesia. Menurut data dari Himpunan Industri Alat Berat Indonesia (HINABI) kebutuhan akan alat berat di Indonesia setiap tahun meningkat. Pada 2011 produksi alat berat 7.000 unit, sedangkan permintaan pasar membutuhkan 15.000 unit. Di 2012 produksi alat berat 8.000 unit, sedangkan permintaan pasar membutuhkan 17.000 unit. Di 2013 produksi alat berat 6,313 unit, sedangkan permintaan pasar membutuhkan 14.000 unit. Fakta ini membuka peluang yang lebih besar bagi industri alat-alat berat untuk lebih berkembang. Pasokan alat berat Indonesia sebagian besar masih impor dan sebagian dirakit di dalam negeri. Pada 2012 nilai impor mencapai US\$ 15 miliar, yang sebagian besar dari China. Meskipun demikian Indonesia juga mengekspor alat berat dengan nilai ekspor mencapai US\$ 560 juta.

Pada saat ini untuk pembuatan alat berat (manufaktur) dilakukan oleh sejumlah perusahaan di Indonesia. PT Komatsu
Indonesia memproduksi alat berat merek Komatsu yang dipasarkan PT United Tractor Tbk, merek Caterpillar dipasarkan oleh PT Trakindo Utama. Juga merek Hitachi dipasarkan oleh PT Hexindo Adi Perkasa. PT Caterpillar Indonesia merupakan salah satu perusahaan manufaktur produsen alat-alat berat di Indonesia. PT Caterpillar Indonesia sedang menghadapi persaingan yang semakin ketat dengan produsen alat-alat berat lainnya, baik dari dalam negeri maupun dari luar negeri. Oleh karena itu, PT Caterpillar Indonesia dituntut untuk selalu berusaha meningkatkan kinerja perusahaan agar dapat memenangkan pasar alat berat di Indonesia. PT Caterpillar Indonesia melakukan perubahan suatu konsep menyeluruh tentang sistem bisnis yang dilakukan untuk bisa menghasilkan produk dengan kualitas tinggi dan harga yang terbaik.

Alat berat dengan merek dagang Caterpillar di Indonesia dipasarkan oleh sebuah perusahaan nasional yaitu PT Trakindo Utama yang ditunjuk sebagai agen tunggal penjualan dan pelayanan (sales and service). Di samping itu, PT Caterpillar Indonesia juga melakukan ekspor ke beberapa pelanggan luar negeri seperti Malaysia, Vietnam, Philipina, dan Mexico. Biaya impor komponen PT Caterpillar Indonesia pada 2012 dan 2013 mencapai US\$ 11 juta dengan biaya terbesar pada transportasi yang mencapai $38 \%$. Oleh karena itu, untuk bisa menjadi pemenang di pasar alat berat diperlukan kebijakan-kebijakan dan strategistrategi yang terintegrasi dan diharapkan dapat berkontribusi secara kongkrit dan signifikan dalam menjalankan bisnis baik jangka pendek maupun jangka panjang.

Era Globalisasi yang berimplikasi pada terbukanya pasar bebas membawa persaingan yang berat pada pelaku ekonomi. Dibutuhkan sesuatu yang memiliki nilai jual lebih agar dapat dikenal dan memperoleh posisi dalam pasar internasional. PT Caterpillar Indonesia dalam proses produksinya banyak menggunakan komponen-komponen baik dalam negeri (lokal komponen) maupun dari luar negeri (impor komponen). Untuk itu pokok permasalahan yang sering terjadi adalah pada tingginya biaya untuk 
mendapatkan komponen (parts impor) dari luar negeri, khususnya komponen impor dari China dan Jepang yang nilai inland freightnya sangat tinggi. Selain itu permasalahan yang timbul adalah pada nilai bea masuk dan biaya transportasi/trucking. Awalnya proses impor tersebut menggunakan pengiriman dengan cara dan metode lama, dimana setiap supplier mengirim masing-masing komponen dengan cara Less than Container Loaded (LCL). Hal ini yang menyebabkan biaya menjadi tinggi dan tidak efisien. Maka diperlukan cara dan metode baru yang efektif untuk pembelian komponen dan pengadaan bahan baku dari supplier/source yang di China maupun di Jepang.

Sistem transportasi yang terkontrol dan terintegrasi (consolidation) sehingga biayabiaya transportasi yang timbul dapat ditekan menjadi lebih mudah dan murah dalam hal pengiriman komponen impor tersebut. Di samping itu agar kelangsungan proses produksi dapat terpenuhi sesuai yang direncanakan, maka dibutuhkan team transportasi, supply chain dan logistik dengan pengendalian secara terpadu dan terintegrasi. Sistem tersebut meliputi sistem perencanaan kedatangan barang, sistem transportasi, sistem pengawasan persediaan barang, dan sistem pengendalian biaya secara keseluruhan. Pada 2014 perusahaan melakukan perubahan pada divisi supply chain dengan meleburnya bagian logistik menjadi team dari Global Supply Network Division (GSND) termasuk bagian transportasi di dalamnya. Yaitu, salah satu divisi yang memegang peranan sangat penting di dalam perusahaan untuk mendatangkan komponen dengan cepat dan tepat waktu juga biaya yang terkontrol secara signifikan. Aktivitas divisi tersebut mulai dari pengawasan pembelian di negara asal barang (source), biaya di negara asal (inland freight), biaya pengapalan (ocean freight), biaya pengeluaran barang dari pelabuhan, dan storage di dalam negeri. Proyeksi penghematan yang didapatkan menjadikan penelitian ini perlu dilakukan.

Permasalahan yang utama dalam pengadaan barang impor selama ini adalah tingginya biaya di negara asal pengiriman yang mencapai 38\% dari nilai barang tersebut, dan terbesar adalah biaya transportasi dari negara asal barang baik China maupun Jepang. Biaya pengiriman barang dipengaruhi jarak dari pabrik ke pelabuhan muat dan juga biaya pengapalan. Jika menggunakan metode LCL yang dihitung berdasar ukuran atau berat barang tersebut akan menimbulkan biaya besar. Perusahaan perlu melakukan perubahan dalam cara pengiriman dari metode LCL ke metode konsolidasi yakni menggunakan kontainer tersendiri untuk mendapatkan efisiensi biaya pengiriman yang bertujuan menurunkan biaya transportasi serta dapat berdampak pada biaya produksi guna mendapatkan keuntungan lebih besar. Semua biaya yang timbul harus dikontrol secara tepat dan benar, karena pada proses pengiriman impor tersebut banyak dipengaruhi oleh beberapa permasalahan. Antara lain biaya yang timbul di negara asal (inland freight), biaya pengiriman laut (ocean freight), biaya customs clearances, biaya pengiriman barang ke perusahaan (inland trucking), dan penumpukan (storage).

Dalam analisa pada tahun 2012 dan 2013 terlihat presentase pada empat permasalahan tersebut yang perlu ditindak lanjuti yaitu trucking, storage, freight, dan duty. Sehingga peluang penghematan dan efisiensi biaya yang timbul dapat dilakukan secara tepat dan akurat dengan perencanaan yang lebih baik ke depan. Atas dasar tersebut penulis menganalisa permasalahan yang terjadi dalam proses impor tersebut dengan judul "Analisis Efisiensi Biaya Perbandingan Metode LCL dan Konsolidasi pada Proses Impor Komponen PT Caterpillar Indonesia dari China dan Jepang." Adapun perumusan masalah yang dimunculkan adalah:

a. Apakah ada perbedaan efisiensi biaya storage dalam proses impor antara metode LCL dengan metode konsolidasi?

b. Apakah ada perbedaan efisiensi biaya trucking dalam proses impor antara metode LCL dengan metode konsolidasi? 
Achsanul Nashir, Analisis Efisiensi Biaya Perbandingan Metode LCL Dan Konsolidasi...

c. Apakah ada perbedaan efisiensi biaya freight dalam proses impor antara metode LCL dengan metode konsolidasi?

d. Apakah ada perbedaan efisiensi biaya rata-rata keseluruhan dalam proses impor antara metode LCL dengan metode konsolidasi?

\section{KAJIAN LITERATUR}

\section{a. Pengertian Administrasi}

Secara naluriah manusia ingin selalu bersama dalam suatu kelompok. Hal ini semakin terasa atau tampak dalam usaha memenuhi kebutuhan hidup yang tidak dapat dilaksanakan secara individual. Kebutuhan yang menimbulkan tujuan bersama, tentu menghendaki suatu kerjasama dari kelompok manusia. Sebelum melakukan tindakan untuk mencapai tujuan yang diharapkan, maka diperlukan pemikiran-pemikiran terlebih dahulu sehingga proses pelaksanaan pencapaian tujuan itu dapat dijalankan sesuai dengan tujuan yang telah ditetapkan. Administrasi menurut pengertian sempit seringkali diartikan sebagai ketatausahaan seperti kegiatan kearsipan dan surat menyurat. Pengertian sempit demikian berkaitan dengan istilah 'administratie' dalam Bahasa Belanda dan 'clerical work' dalam Bahasa Inggris. Administrasi ini merupakan bagian atau aspek manajemen dan menurut Soewarno Handayaningrat (2008:2) dalam bukunya Pengantar Studi Ilmu Administrasi dan Manajemen adalah kegiatan catat-mencatat, surat-menyurat, pembukuan ringan, ketikmengetik agenda, dan sebagainya yang bersifat teknis ketatausahaan.

Pengertian administrasi dalam Bahasa Indonesia sehari-hari dalam arti sempit yang dikutip Sofwan Badri (2008: 1) dalam buku Konsep-Konsep Dasar Administrasi, Administrasi Negara dan Administrasi Pembangunan, yaitu tata usaha kantor, tata usaha wakat, tulis menulis, clerical work. Pengertian ini dari kata bahasa Belanda 'administratie'. Dalam arti luas administrasi yaitu segala kegiatan sekelompok orang yang bekerja sama secara rasional untuk mencapai tujuan bersama. Pengertian ini dari Bahasa Inggris 'administration'. Sementara pengertian administrasi secara umum banyak dikemukakan para ahli. Di antaranya menurut Sondang P. Siagian (2008: 9) dalam bukunya Filsafat Administrasi mengatakan bahwa administrasi adalah keseluruhan proses kerjasama antara dua orang manusia atau lebih yang didasarkan atas rasionalitas tertentu untuk mencapai tujuan yang telah ditentukan sebelumnya. Sedangkan menurut Herbert A. Simon sebagaimana dikutip Dan Suganda (2001: 9) dalam bukunya Administrasi Strategi, Taktik dan Teknik Penciptaan Efisiensi mengatakan bahwa administrasi dapat dirumuskan sebagai kegiatan-kegiatan kelompok-kelompok yang bekerjasama mencapai tujuan-tujuan bersama.

\section{b. Pengertian Manajemen Operasional}

Manajemen produksi dan operasi merupakan salah satu fungsi penting dalam perusahaan (organisasi), selain manajemen sumber daya manusia, manajemen pemasaran, dan manajemen keuangan/akuntansi yang menghasilkan produk (barang/jasa). Berikut pengertian manajemen produksi/operasional menurut para ahli. Assauri (2004: 12) berpendapat bahwa manajemen produksi dan operasi merupakan proses pencapaian dan pengutilisasian sumber-sumber daya untuk memproduksi atau menghasilkan barangbarang atau jasa-jasa yang berguna sebagai usaha untuk mencapai tujuan dan sasaran organisasi. Sedangkan Krawjewsky dan Ritzman (2006: 2) mengemukakan bahwa manajemen operasi mengacu pada arah dan pengendalian proses yang mengubah masukan menjadi produk dan jasa. Selain itu Heizer dan Render (2001: 2) mengemukakan tentang manajemen operasional sebagai serangkaian kegiatan yang membuat barang dan jasa melalui perubahan dari masukan menjadi keluaran. Dapat ditarik kesimpulan bahwa manajemen operasional adalah proses pencapaian tujuan organisasi melalui pengarahan dan pengendalian serangkaian kegiatan yang menggunakan sumber daya yang dimiliki untuk merubah input menjadi output, baik barang maupun jasa.

\section{c. Pengertian Kekuatan Pasar}

Kekuatan pasar dapat didefinisikan sebagai kemampuan pelaku usaha atau 
kelompok usaha untuk mendapatkan harga yang eksesif dan lebih mahal dibandingkan dengan harga kompetitif dalam jangka waktu tertentu (U.S. Antitrust Agenccies dalam Burtis 2010). Definisi lain dari kekuatan pasar adalah kemampuan untuk menetapkan harga yang tinggi di tengah minimnya kompetisi dan sering diiringi dengan adanya tambahan margin biaya. Kekuatan pasar dapat didefinisikan pula sebagai kemampuan satu pelaku usah untuk meningkatkan harga dan membatasi output. Kekuatan pasar memiliki kemampuan untuk mengontrol kuantitas produksi dan harga. Untuk itu, perlu dianalisis isu pasar yang bersangkutan pada industry alat berat dengan mengetahui berapa besar pasar yang terkait dalam industry tersebut, bagaimana elastisitas permintaan pasar, seberapa besar pelaku usaha tersebut, bagaimana kondisi elastisitas suplai terhadap kompetitor, dan sejauhmana hambatan di pasar bersangkutan (Noh SS, 2009).

Terbentuknya kekuatan pasar ini dapat dikontribusikan oleh produk yang telah mengalami diferensiasi, akseptasi yang tinggi terhadap merek tertentu, kemampuan iklan yang mampu mempengaruhi persepsi konsumen, konsumen yang loyal, dan ketidaksempurnaan informasi pada konsumen (Kotler dan Hermawan). Menurut Taylor (2009), untuk melihat dampak kekuatan pasar terhadap persaingan usaha dapat diperhatikan dari pasar yang relevan dari industri bersangkutan, besarnya pangsa pasar, dan seberapa besar kekuatan pasar dari pelaku usaha yang memiliki pangsa pasar besar. Pembuktian kekuatan pasar ini dapat diukur dari elastisitas permintaan dan rasio harga per biaya. Menurut Burtis (2010), mengukur kekuatan pasar dapat dilihat dari kemampuan pelaku usaha untuk meningkatkan harga melebihi harga persaingan, dapat dilihat dari penerapan price cost margin, tingkat elastisitas permintaan, serta kemampuan harga suatu produk untuk mempengaruhi kuantitas pasar dan harga.

Selanjutnya menurut Sheherd (1997), kekuatan pasar dapat berefek pada harga, keuntungan, dan tingkat efisiensi pangsa pasar yang dapat mencerminkan kekuatan pasar produk tertentu pada suatu industri. Pangsa pasar di bawah 50\% jarang terbukti memiliki kekuatan monopoli. Pangsa pasar antara $50-70 \%$ biasanya memiliki potensi untuk monopoli. Adapun pangsa pasar di atas $70 \%$ umumnya terbukti memiliki kekuatan monopoli. Untuk mengantisipasi pangsa pasar yang dapat mengarah pada kekuatan pasar, maka segera mendefinisikan pasar setiap saat, hambatan pasar atau kemampuan untuk ekspansi, apakah produk masih bersifat homogenus atau telah terdiferensiasi, prospek pasar masa akan datang, dan mempertimbangkan unit penjualan dan kapasitas. Penguasaan pasar dapat dilihat seberapa besar konsentrasi masing-masing komoditas menggunakan HerfindahlHirschman Index (HHI), yaitu angka indeks yang digunakan untuk mengetahui seberapa besar konsentrasi pasar yang dimilik oleh pelaku usaha tertentu pada pasar Industri bersangkutan (Lipczynski dan Wilson, 2001).

Angka HHI dapat mengukur terjadinya tingkat konsentrasi pelaku usaha di pasar bersangkutan pada waktu tertentu. Angka HHI sebesar 1,8 menjadi indikator konsentrasi pasar. Bila lebih besar dari 1,8 maka pelaku usaha tersebut memiliki konsentrasi tinggi, cenderung menguasai pasar, serta memiliki potensi terjadinya persaingan usaha tidak sehat. Sementara di bawah 1,8 menunjukkan pelaku usaha tersebut memiliki konsentrasi rendah dan pasar tidak didominasi oleh satu pelaku usaha. HHI ini hanya dapat digunakan untuk menilai kondisi persaingan pada pasar bersangkutan, tetapi tidak melihat potensi dominasi masingmasing pelaku usaha yang berada pada industri tersebut, angka HHI yang tinggi dapat menunjukkan bahwa komoditas tertentu hanya diadakan oleh sekelompok pengusaha. Kondisi ini menunjukkan minimnya persaingan pada komoditas tersebut. Kondisi berbeda terjadi bila angka HHI rendah, menunjukkan telah banyak pelaku usaha yang bersaing pada pasar komoditas bersangkutan karena banyaknya pelaku usaha yang terlibat di pasar (Elhauge dan Geradin 2007) 


\section{d. Pengertian Efisiensi}

Efisiensi merupakan suatu ukuran keberhasilan yang dinilai dari segi besarnya sumber/biaya untuk mencapai hasil dari kegiatan yang dijalankan Menurut Dearden yang diterjemahkan oleh Agus Maulana dalam bukunya yang berjudul 'Sistem pengendalian Manajemen.’ Pengertian efisiensi dapat diartikan sebagai kemampuan suatu unit usaha untuk mencapai tujuan yang diinginkan, efisiensi selalu dikaitkan dengan tujuan organisasi yang harus dicapai oleh perusahaan (Agus Maulana, 1997: 46). Pengertian efisiensi itu sendiri telah didefinisikan oleh banyak pakar ekonomi dan manajemen di antara adalah pengertian efisiensi menurut Malayu S.P Hasibuan. Yaitu perbandingan terbaik antara input (masukan) dan output (hasil), antara keuntungan dengan biaya (antara hasil pelaksanaan dengan sumber yang digunakan) seperti halnya juga hasil optimal yang dicapai dengan penggunaan sumber yang terbatas (1994: 7). Sedangkan menurut Supriyono dalam bukunya berjudul 'Akuntansi Manajemen II' mendefinisikan efisiensi sebagai suatu unit dapat bekerja dengan baik, sehingga dapat mencapai hasil atau tujuan yang diharapkan (1997: 7). Dari pengertian tersebut dapat disimpulkan bahwa efisiensi merupakan kemampuan perusahaan dalam menjalankan aktivitas untuk memperoleh hasil tertentu dengan menggunakan masukan (input yang sederahnya-rendahnya) untuk menghasilkan suatu keluaran (output), dan juga merupakan kemampuan untuk menyelesaikan pekerjaan dengan benar.

Suatu pusat pertanggungjawaban dikatakan efisiensi jika pusat pertanggungjawaban tersebut (1) menggunakan sumber atau biaya atau masukan lebih kecil untuk menghasilkan keluaran dalam jumlah yang sama, (2) menggunakan sumber atau biaya atau masukan yang sama untuk menghasilkan keluaran dalam jumlah yang lebih besar. Di dalam masyarakat yang bertambah lama bertambah besar dan kompleks, lingkungan tidak lagi menyediakan kebutuhan-kebutuhan manusia secara tak terbatas. Bertambah lama sumber-sumber menjadi bertambah terbatas, sehingga orang harus berpikir bagaimana memanfaatkan sumber-sumber kebutuhan yang ada dengan sebaik-baiknya. Pemanfaatan yang sebaik-baiknya inilah yang merupakan salah satu dasar dari prinsip efisiensi. Sehubungan dengan pernyataan di atas, Sugandha (2009: 86) memberikan pendapat bahwa dalam bidang pemerintahan pun di dalam administrasi negara seperti juga dalam prinsip-prinsip administrasi telah diterima asumsi bahwa efficiency the criterion by which the administration of government agencies is to be judged yang berarti efisiensi telah menjadi ukuran keberhasilan administrasi badan-badan pemerintahan.

The Liang Gie (2009: 187) memberikan definisi mengenai efisiensi adalah sebuah pengertian atau konsepsi yang menggambarkan perbandingan terbaik antara suatu usaha dengan hasilnya. Menurut Soedjadi (2005: 39) untuk mencapai suatu efisiensi haruslah memenuhi syarat-syarat: (a) berhasil guna (effective) yakni untuk menyatakan bahwa kegiatan telah dilaksanakan dengan tepat dalam arti target tercapai sesuai dengan waktu yang ditetapkan (target achieved), (b) ekonomi (economy) yaitu untuk menyebutkan bahwa di dalam usaha pencapaian tujuan kerja, maka biaya, tenaga kerja, material, peralatan, waktu, ruangan, dan lain-lainnya telah dipergunakan dengan setepat-tepatnya sebagaimana yang telah ditetapkan dalam perencanaan dan tidak terjadi pemborosan, penyelewenganpenyelewengan maupun korupsi, (c) pelaksanaan kerja dapat dipertanggungjawabkan (responsible performance) yaitu untuk membuktikan bahwa di dalam pelaksanaan kerja sumbersumber telah dimanfaatkan dengan setepattepatnya dan tidak terjadi pemborosanpemborosan maka kegiatan itu haruslah dilaksanakan secara bertanggung jawab sesuai dengan yang telah ditetapkan dalam perencanaan, (d) pembagian kerja yang nyata (real and factual distribution of work) yaitu berdasarkan logika bahwa tidak mungkin manusia seorang diri mengerjakan segala macam pekerjaan dengan baik, (e) rasionalitas wewenang dan tanggung jawab (rationality of 
authority and responsibility) artinya jangan sampai seseorang mempunyai wewenang yang lebih besar dari pada tanggung jawab yang dimiliki, (f) prosedur kerja yang praktis dapat dikerjakan dan dapat dilaksanakan (practicable, workable, and applicable procedures) yaitu untuk menegaskan bahwa organisasi dan manajemen adalah kegiatan praktis.

Azas efisiensi kerja Menurut Sedarmayanti (2008: 131) ada lima, yaitu azas perencanaan, azas penyederhanaan, azas penghematan, azas penghapusan, dan azas penggabungan sehingga dapat menghemat waktu kerja. Seseorang yang bekerja dengan cara yang efisien akan dapat mencapai kesuksesan dalam bidang pekerjaan, karena pegawai dapat bekerja lebih baik daripada pegawai lain yang tidak mempunyai jiwa efisiensi.

\section{e. Pengertian Efektivitas Kerja}

Efektifitas pada dasarnya berasal dari kata efek dan digunakan dalam istilah ini sebagai hubungan sebab akibat. Efektifitas dapat dipandang sebagai suatu sebab dari variabel lain. Efektifitas berarti bahwa tujuan yang telah direncanakan sebelumnya dapat tercapai atau dengan kata sasaran tercapai karena adanya proses kegiatan. Gibson (2012: 51) mengatakan bahwa efektifitas adalah pencapaian sasaran dari upaya bersama. Derajat pencapaian sasaran menunjukkan derajat efektifitas. Agar pelaksanaan administrasi lebih mencapai hasil seperti direncanakan, mencapai sasaran tujuan yang ingin dicapai dan lebih berdaya hasil. Efektivitas dapat diartikan sebagai keberhasilan atas usaha dan tindakan. Pada organisasi pemerintah yang orientasi adalah pelayanan kepada masyarakat, maka efektivitas dapat diartikan sebagai daya guna dan hasil guna dari setiap pelayanan yang dilakukan kepada masyarakat. Salah satu tujuan yang ingin dicapai oleh manajemen adalah terciptanya efektivitas kerja pegawai dalam menjalankan tugas dan pekerjaan yang menjadi tanggung jawabnya masing-masing sesuai dengan standar kerja yang telah ditetapkan organisasi.

Pengertian efektivitas menurut Siagian (2006: 151) yaitu penyelesaian pekerjaan tepat pada waktu yang telah ditetapkan, artinya apakah pelaksanaan suatu tugas dinilai baik atau tidak, tergantung pada bilamana tugas itu diselesaikan atau tidak, terutama menjawab pertanyaan bagai mana cara melaksanakan dan berapa biaya yang disalurkan untuk itu. Secara sederhana bila pekerjaan dilakukan sesuai dengan prosedur, maka pekerjaan tersebut dikatakan baik. Dengan langkah-langkah yang sesuai dengan prosedur, maka pekerjaan satu dan lainnya tidak bertabrakan sesuai dengan planning yang ada. Menurut Westra (2009: 147), efektivitas adalah suatu perbuatan dengan maksud tertentu yang memang dikehendaki, maka orang itu dikatakan efektif bila menimbulkan akibat sebagaimana dikehendaki. Banyak faktor yang mempengaruhi seseorang untuk dapat bekerja dengan cara yang efektifitas, di antaranya bentuk dan susunan serta permukaan meja perlu direncanakan dengan baik agar dapat membantu untuk tidak merasa terlalu lelah, dapat menghemat tenaga, usaha dan waktu,.

\section{f. Pengertian Biaya}

Biaya adalah sejumlah pengeluaran yang dikaitkan dengan hasil yang diharapkan pada masa yang akan datang. Biaya dapat pula diartikan sebagai pengorbanan sumber ekonomis yang diukur dalam satuan uang yang telah terjadi, sedang terjadi, atau yang kemungkinan akan terjadi untuk tujuan tertentu. Besarnya kecilnya biaya tetap dipengaruhi oleh kondisi perusahaan jangka panjang, teknologi, metode, serta strategi manajemen. Pembebanan biaya secara akurat ke objek biaya sangatlah penting. Keakuratan adalah suatu konsep yang relative dan harus dilakukan dengan wajar serta logis terhadap penggunaan metode pembebanan biaya. Tujuannya adalah mengukur dan membebankan biaya terhadap sumber daya yang dikonsumsi oleh objek biaya. Pembebanan biaya yang terdistorsi dapat 
menghasilkan keputusan yang salah dan evaluasi yang buruk, sehingga dapat menciptakan pemborosan. Faktor sumber daya manusia sebagai salah satu faktor yang ikut dalam penentuan pencapaian keuntungan perusahaan. Sumber daya manusia tidak boleh terlepas dari perhatian dengan kebutuhan perusahaan agar diperoleh karyawan yang cakap dan handal. Kebijakan atau aturanaturan yang dikeluarkan terutama ditujukan untuk mendapatkan sumber daya manusia yang benar-benar terampil, cakap dan profesional.

\section{g. Pengertian dan Konsolidasi Less than Container Loaded (LCL)}

LCL merupakan jenis pengiriman barang tanpa menggunakan container atau dengan kata lain parsial. Jika kita menggunakan pengiriman LCL maka barang yang kita kirim itu ditujukan ke gudang penumpukan dari shipping agent, lalu dari gudang penumpukan tersebut akan mengumpulkan barang-barang kiriman LCL yang lain. Sehingga memenuhi kuota untuk dapat dimuat di dalam container. Peranan freight forwarder dalam konsolidasi barang makin penting karena pemilik barang lebih senang berhubungan dengan satu pihak saja, yang akan mengambil alih semua tanggung jawab sejak barang diserahkan di gudang pengirim sampai barang diterima di gudang penerima (one stop shipping). Konsolidasi memberikan "door to door service" yang tidak dilakukan oleh perusahaan forwarding. Selain itu kelebihan konsolidasi ada pada penarikan freight-nya yang berdasarkan tonase barang. Dalam prakteknya ada beberapa hal yang perlu diperhatikan atas penerimaan jasa konsolidasi barang dalam peti kemas (FCL). Hal tersebut dikarenakan terdapat kemungkinan terjadi penundaan pengiriman muatan karena masih tersedia space kosong dalam peti kemas yang masih bisa untuk dimuati barang. Bagi pihak shipper sebagai pengguna jasa, akan terkena biaya yang biasa disebut sebagai inventory cost, sedangkan bagi freight forwarder akan terkena tambahan biaya selama penyimpanan barang shipper. Dimana yang dimaksud dengan inventory cost yaitu biaya yang muncul sebagai dampak penyimpanan barang di gudang yang melebihi batas waktu penyimpanan karena keterlambatan dalam pengiriman barang. Bagi pihak pelayaran juga akan menanggung opportunity cost akibat penundaan pengiriman karena slot pada kapal yang harusnya terisi menjadi tidak terisi. Jika freight forwarder tetap melaksanakan pengiriman maka biaya total akan jauh lebih besar karena space kosong yang tersedia dalam peti kemas merupakan pendapatan (revenue) yang hilang.

\section{METODE PENELITIAN}

Pendekatan penelitian ini menggunakan metode penelitian deskriptif kualitatif, karena mempertimbangkan fokus penelitian yang akan dicapai oleh peneliti. Penulis juga ingin mengangkat fenomena dan hambatanhambatan yang ada dalam penerapan sistem manajemen, berusaha mencari pembahasan tentang permasalahan yang ada serta menjabarkan secara deskriptif hasil penelitian yang telah dicapai. Adapun metode penelitian yang akan digunakan adalah: (a) field research yaitu melakukan kegiatan penelitian dan survei lapangan dengan menggali datadata yang ada, mengumpulkan data-data, mengelompokkan data-data sehingga dapat memberikan gambaran secara jelas tentang pokok permasalahan yang terjadi di lapangan, (b) library research yaitu melakukan penelaahan melalui buku-buku, majalahmajalah serta literatur yang terkait dengan pengendalian mutu, sehingga penulis memperoleh referensi untuk melakukan penelitian lapangan, mengidentifikasi masalah dan menganalisa. Untuk objek penelitian yang diambil adalah PT Caterpillar Indonesia yang berlokasi di Jalan Raya Narogong KM 19 Cileungsi - Bogor.

Untuk memperoleh data yang diperlukan dalam penelitian ini, penulis menggunakan teknik pengumpulan data yang diperoleh dari hasil pengukuran dan laporan yang dilakukan di bagian impor dan transportasi untuk biaya yang dikeluarkan selama proses impor. Data yang penulis kumpulkan untuk 2014. Pengumpulan data yang didapat pada saat penelitian yaitu data sekunder yang diperoleh atau dikumpulkan peneliti dari berbagai sumber yang telah ada, baik berasal dari pihak 
dalam perusahaan maupun dari luar perusahaan. Dalam hal ini penulis menggunakan data internal, yaitu data yang dimiliki oleh perusahaan 2014. Sedangkan uji keabsahan data merujuk pada Lincoln and Guba (1985: 301-331) terdapat empat kriteria untuk menentukan apakah data yang diperoleh sudah mencapai tingkat keabsahan (trustworthiness criteria). Kriteria pertama adalah credibility atau dapat dipercaya dan telah memenuhi unsur prolonged engagement yaitu keterlibatan yang cukup lama yakni data tersebut telah melalui proses yang cukup lama diolah dan diteliti. Karena sifat pendekatan penelitian kualitatif yang iterated until redundancy yakni berulang kali sampai tercapai kejenuhan. Selanjutnya data dapat dikatakan telah memenuhi kepercayaan apabila memenuhi kriteria persistent observation, dalam arti peneliti secara konsisten dan terus menerus melakukan pengamatan.

Kriteria kedua adalah transferability yakni dapat dialihkan. Dalam hal ini peneliti merumuskan hipotesis kerja pada konteks A dapat dialihkan ke konteks $\mathrm{B}$, dalam hal ini dibutuhkan kesamaan dan kecocokan yakni tingkat kesesuaian antara yang mengirim dan yang menerima hipotesis kerja tersebut. Kriteria ketiga adalah dependability artinya proses telah dilakukan secara fair dan data telah lebih baik. Kriteria keempat adalah conformability yaitu dapat ditegaskan yakni catatan, data atau laporan telah fall within acceptable professional, legal and ethical limits (Yvonna S. Lincoln and Egon G. Guba, 1985: 318-319). Selanjutnya metode analisis data yang digunakan adalah induktif data yang mempunyai kesamaan dengan content analysis, yakni suatu proses yang bertujuan mengungkapkan informasi yang tersembunyi dan menjadikan informasi itu menjadi eksplisit. Proses selanjutnya untuk mengungkap informasi yang tersembunyi adalah menerapkan unitizing dan categorizing. Unitizing adalah proses coding, yakni data mentah secara sistematis ditransformasikan dan dihimpun kepada unitunit yang cenderung memiliki deskripsi yang tepat dari inti sifat-sifat yang relevan. Categorizing adalah proses data yang sudah disatukan dan sebelumnya diorganisasikan dalam beberapa kategori sedemikian rupa. Dengan begitu tersedia kesimpulan deskripsi atau informasi tentang konteks atau kedudukan dari mana unit-unit itu berasal. Tempat penelitian di PT Caterpillar Indonesia yang berlokasi di Jalan Raya Narogong KM 19 Cileungsi - Bogor. Adapun waktu penelitian pada 1 September 2014 sampai dengan 30 Desember 2014.

\section{HASIL PENELITIAN DAN PEMBAHASAN \\ a. Gambaran Umum}

Pada 1977 pemerintah Indonesia menekankan agar diadakan sumber daya lokalisasi alat-alat berat. Dengan disetujui dan ditandatangani oleh PT Sanggar Sarana Baja (SSB) untuk komponen yaitu attachment seperti bucket (unit Hexavator) dengan lisensi CATERPILLAR (merk dari USA). Hingga 1979 muncul perusahaan alat-alat berat dari Korea yang bernama Hyundai atau Halla yang telah menyanggupi membuat lokalisasi sebesar $100 \%$ dengan jangka waktu lima tahun dengan permintaan monopoli ke seluruh Indonesia. Kemudian pada 1980 muncul hasil tenggang waktu dari rekomendasi gol terms of reference, dimana penanam modal asing harus ada kerja sama dengan pemerintah khususnya perusahaan Barata (milik pemerintah) sebesar 50\%:50\% dengan persetujuan satu perusahaan, monopoli penjualan atau pemasaran, dengan dipakainya Deutze Engine hasil produksi PT Boma Bisma Indra, lokasi perusahaan direncanakan di daerah Cilegon, pembuatan lokasi mencapai $100 \%$ dalam jangka waktu 5 tahun bersamaan itu pula untuk mencapai hasil usaha.

Caterpillar bersama perusahaan alat-alat berat lain seperti Komatsu. Mitsubishi. Hitachi dan Furukawa mengajukan usulan yang menyatakan proyek tidak berjalan, penghapusan program tidak tercapai, perencanaan perizinan yang memadai, resiko dari monopoli yang tidak terpengaruh besar 
Achsanul Nashir, Analisis Efisiensi Biaya Perbandingan Metode LCL Dan Konsolidasi...

terhadap dua perusahaan. Diskusi berjalan terus hingga timbul peringatan dari perusahaan Komatsu mengenai resiko pengeluaran dari penjualan. Pada 1981, Caterpillar mengajukan usulan untuk mendirikan perusahaan yang mencakup masalah perlindungan terhadap perusahaan tersebut antara lain bea masuk dan tata niaga. Pada 14 September 1982 merek Amerika yaitu Caterpillar mengajukan proposal investasi di Indonesia dan direalisasi pada 7 Desember 1982.

Pengajuan usulan ini berdasarkan pertimbangan perkembangan dan kemajuan pembangunan di Indonesia dan lahir perusahaan yang bernama PT Natra Raya. Realisasi PMA ini disetujui langsung oleh presiden melalui badan pemerintah yaitu Badan Koordinasi Penanaman Modal (BKPM). Perizinan ini tidak terpengaruh oleh rentang daya penerapan peraturan pemerintah untuk pembatasan import alat-alat berat. Keterangan status setelah mendapatkan realisasi adalah sebagai berikut lokasi berada di Jalan Narogong Km 19 Cileungsi. Bogor Jawa Barat, aktifitasnya perusahaan equipment construction dan generator set, disahkan pada 17 Desember 1982, produksi pertama pada 5 Maret 1984 berupa tipe tractor D7G, tipe tractor D6G, dan tipe loader 920. Pada 1983 perakitan masih di PT Trakindo Utama dengan jumlah karyawan 38 dan sambil menunggu pabrik untuk siap dipakai. Dengan pembagian saham Caterpillar sebesar $80 \%$ dan PT. Trakindo Utama sebesar $20 \%$.

Untuk kapasitas produksi pada 1985 sudah ada Tractor D7G sebanyak 30 unit per tahun, tractor D6G sebanyak 30 unit per tahun, loader 920 yakni 20 unit per tahun. Dikarenakan permintaan semakin meningkat sedangkan pengadaan kurang maka perbandingan kebijaksanaan dari pemerintah untuk alat-alat berat dikeluarkan agar bisa memenuhi permintaan secara maksimal. Ada dua jenis yang mendapat realisasi pada 1985 antara lain untuk barang import berdasarkan Complete Knock Down (CKD) pada 1983 sampai dengan $10 \%$ dan Built-up (CBU)-PPN $10 \%$ - 0\% (G/84) Bea masuk (BM) 5\% - 20\% (PB3). Selanjutnya untuk non tarif juga diberikan, dimana bea masuk tidak dibebankan dengan ketentuan melalui penyaluran atau agen tunggal yang mempunyai perizinan. Perlindungan ini berlaku hanya untuk alat-alat berat $300 \mathrm{HP}$ berjenis Buldozer (tractor) $75-300 \mathrm{HP}$, Wheel Loader 100 - 300 HP, Motor Grader 100 - $150 \mathrm{HP}$, dan Hexavator 60 - $150 \mathrm{HP}$.

Perkembangan PT Natra Raya berjalan dengan keadaan yang sangat pesat yakni di luas areal $10 \mathrm{Ha}$, dari hanya ada ruang kantor dan beberapa gedung di 1982 dan sampai pada awal 2014 mempunyai beberapa gedung dan alat-alat produksi antara lain. Seperti gedung fabrikasi, gedung assembly, gedung office, gedung pengecatan, gedung logistik, gedung maintenance, dan area parkir motor. Operasional perusahaan juga ditunjang dengan pengadaan komputer dan sistem komputerisasi secara lokal atau internasional. Dari produksi yang hanya kurang dari 200 unit per tahun dengan karyawan 38 orang di 1982 hingga mencapai kapasitas produksi di atas 1000 unit per tahun dengan karyawan kurang lebih 500 orang. Mengikuti alih teknologi dari Amerika dan hasil kualitas yang berstandar Caterpillar. Pada awal Maret 2010 nama PT Natra Raya berubah nama menjadi PT Caterpillar Indonesia. Pergantian nama ini karena saham yang dimiliki Caterpillar Inc sudah $100 \%$, dari sebelumnya 20\% PT Trakindo Utama dan 80\% Caterpillar Inc.

Selama perkembangan perusahaan, telah 4 kali melakukan perbaikan perizinan sesuai peraturan pemerintah. Antara lain pada 17 Februari 1983 SK No. 55/M/SK/2/1983; pada 23 April 1984 SK No. 138/SK/4/1984; pada 23 Juni 1990 SK No. 55/M/SK/6/1990; dan pada 27 Juni 1994 SK No. 289/M/KMK/01/1994. Kawasan pengembangan industri Cileungsi yang dipilih memenuhi kriteria untuk pendirian suatu industri tersebut karena tersedianya tenaga kerja yang murah, tersedianya listrik yang cukup, tersedianya sarana perhubungan darat yang memadai, dan keuntungan-keuntungan lain. Lokasi perusahaan terletak sekitar 50 KM dari Jakarta dan hanya memerlukan waktu sekitar satu jam perjalanan dari Jakarta serta jalan yang dilalui dapat dengan menggunakan trailer sebagai sarana 
transportasi alat-alat berat. Sarana dan prasarana yang dimiliki PT Caterpillar Indonesia dari tahun ke tahun semakin meningkat. Sarana dan prasarana yang dimiliki meliputi sebidang tanah seluas kurang lebih $25 \mathrm{Ha}$, dimana penggunaan sebagai ruang kantor seluas $630 \mathrm{~m} 2$ berfungsi sebagai tempat administrasi perusahaan; ruang machine assembly seluas $3.456 \mathrm{~m} 2$ berfungsi sebagai tempat perakitan alat-alat berat; ruang logistik atau material storage seluas $10.000 \mathrm{~m} 2$ berfungsi sebagai tempat penyimpanan row material dan parts lain sebelum di proses dan di assembly menjadi barang jadi; serta ruang pengecatan dan pengerjaan akhir seluas $1.152 \mathrm{~m} 2$ berfungsi sebagai ruang pengecatan (painting), pencucian unit (washing), pembersihan dan penghalusan unit yang akan di cat dan penyelesaian pengerjaan akhir.

Adapula ruang fabrikasi seluas $5.200 \mathrm{~m} 2$ berfungsi sebagai tempat pengerjaan pengelasan barang-barang lokal seperti radiator guard, blade, bucket, boom, swing frame dan lain-lainnya. Juga untuk pengerjaan 70 machining seperti pemotongan, penekukan, pembubutan dan lain-lainnya; ruang generator seluas $152 \mathrm{~m} 2$ sebagai ruang listrik dari generator set; ruang kantin, klinik, loker dan wc seluas $445 \mathrm{~m} 2$; ruang koperasi; tempat pengolahan limbah; masjid; area parkir motor; lapangan sepak bola; dan sisa lahan untuk area hijau demo dan pengujian alat berat. Selain berupa bangunan gedung, terdapat pula tempat terbuka untuk tempat penyimpanan material (storage), khususnya untuk material yang tidak mudah rusak ataupun karatan dan material yang sudah setengah jadi seperti frame, blad, bucket, track, counter weight dan lain-lainnya. Untuk material yang mudah karatan sebelum disimpan di tempat terbuka, terlebih dahulu dilapisi dengan vaseline atau grease. Areal terbuka selain tempat storage material, juga sebagai tempat parkir unit-unit yang telah dirakit. Untuk itu seluruh lantai 71 di lokasi pabrik dilapisi dengan beton khusus dan juga sebagian tempat dilapisi dengan lembaran baja, agar supaya mampu menahan beban dan getaran yang tinggi akibat alat-alat berat yang sedang berjalan.

Untuk mendukung hal tersebut di atas. pada saat ini (awal 2015) perusahaan sudah menerapkan program-program peningkatan kualitas produk dengan dicapai dan diimplementasikan ke seluruh karyawan. Program-program tersebut antara lain Class A, 6 Sigma, MQ 12005 (Internal Certification), ISO 9001 - 2000 dan CPS (Caterpillar Production System), serta sekarang adalah CQMS (Caterpillar Quality Management System), dan BIQ sebagai pengganti ISO 9001-2000. 72. Semua itu dilakukan untuk memenuhi visi PT Caterpillar Indonesia yakni menjadi pemimpin pasar alat-alat berat di dunia pada 2020 mendatang. Untuk itu, setiap karyawan akan mendapat training wajib dan pilihan sesuai dengan bagian masing-masing yang mengacu kepada tugas dan tanggung jawabnya. Untuk training ini bisa dilakukan di dalam PT Caterpillar Indonesia (in house training) dan di luar (out house). Kebutuhan ini disesuaikan dengan materi training. Untuk pengaturan training ini diatur oleh bagian yang bertanggung jawab yaitu bagian training koordinator, sehingga materi dan karyawan yang mendapat training bisa lebih terpantau dan tercatat. Guna mencapai hasil yang optimum PT Caterpillar Indonesia didukung oleh sistem Enterprise Resource Planning (ERP) yang penggunaan telah mendapatkan sertifikat Class A dari Technical Service Division Caterpillar.

Investasi Pembuatan dan perakitan yang dilakukan di PT Caterpillar Indonesia hanya sebagian dari usaha Caterpillar dalam peningkatan sarana rekanan di Indonesia. Perakitan produk didukung oleh lebih dari 20 perusahaan rekanan di dalam negeri. Tenaga di bagian teknik menjalin hubungan erat dengan para rekanan bukan hanya untuk menjamin dan memenuhi standar spesifikasi serta mutu yang memerlukan ketelitian, tetapi juga peningkatan dalam penekanan biaya produksi dan jadwal pengiriman, dan didukung investasi di atas 150 juta US dollar. Penanaman investasi yang besar ini dalam 
bentuk 74 gedung/pabrik, mesin/peralatan, tenaga kerja dan peningkatan kemampuan rekanan dibuat untuk menjamin agar produk dengan nilai tertinggi diserahkan kepada pelanggan disamping mendukung aspirasi pemerintah dan rakyat Indonesia dalam meningkatkan dasar industri nasional. Untuk itu fasilitas yang diberikan kepada karyawan meliputi keselamatan kerja di lokasi PT Caterpillar Indonesia untuk memasuki kawasan pabrik diwajibkan memakai alat-alat keselamatan kerja ini berlaku bagi semua karyawan dan tamu yang berkunjung di area pabrik. Antara lain sepatu safety, helm, dan kaca mata. Untuk pejalan kaki bila memasuki kawasan pabrik sudah ditetapkan rute tersendiri dan harus didampingi oleh orang dari bagian safety untuk memandu.

Secara rinci alat-alat keselamatan karyawan diwajibkan memakai Alat Pelindung Diri (APD) atau Personal Protective Equipment (PPE) yang digunakan untuk masing-masing bagian, adalah sebagai berikut:

a. Untuk di bagian fabrikasi (welding) PPE yang digunakan antara lain kedok las (welding shield), apron, long slave, pelindung muka (face shield), pelindung kaki, sarung tangan kulit, kedok gerinda, helmet, kaca mata putih dan 75 hitam, respirator, sepatu safety (safety shoes) dan pelindung telinga (ear plug).

b. Untuk di bagian assembly dan logistik PPE yang digunakan antara lain sarung tangan kulit dan kain, kaca mata putih, helmet, masker, sepatu safety (safety shoes), pelindung telinga (ear plug).

Di bidang kesehatan semua karyawan dapat fasilitas jaminan kesehatan dari perusahaan. Baik itu melalui asuransi maupun dari BPJS. Untuk jaminan kesehatan ini karyawan terbagi menjadi dua bagian yaitu karyawan tetap dimana karyawan, istri karyawan, dan maksimal 3 anaknya mendapat jaminan kesehatan dari perusahaan. Serta karyawan tidak tetap (kontrak) yaitu karyawan, istri karyawan, dan maksimal 3 anaknya memperoleh jaminan kesehatan dari BPJS. Untuk di area perusahaan juga tersedia poliklinik dan setiap hari disediakan dokter jaga untuk melayani karyawan baik yang permanen maupun yang kontrak. Untuk di area pabrik setiap bagian telah disediakan kotak P3K (first aid). Adapun fasilitas kesejahteraan yang diperoleh oleh karyawan terbagi atas sarana transportasi untuk karyawan dari berbagai rute sesuai dengan domisili karyawan bertempat tinggal; sarana olah raga yang disediakan adalah tenis meja, tenis lapangan, lapangan bola, futsal, dan bulutangkis baik di dalam lingkungan perusahaan maupun di luar perusahaan (menyewa untuk dimanfaatkan karyawan); dan ketenagakerjaan sejak 1982 banyak mengalami perubahan baik dari jumlah tenaga kerja maupun komposisi pendidikan karyawan.

Untuk kelancaran kegiatan perusahaan baik kegiatan produksi maupun kegiatan penunjang lainnya diperlukan pengaturan yang baik dan benar. Sehingga segala sesuatu dapat saling menunjang untuk tercapainya tujuan organisasi perusahaan. PT Caterpillar Indonesia adalah perusahaan Penanaman Modal Asing (PMA) di bawah naungan Caterpillar Inc. asal Amerika Serikat, maka organisasi perusahaan juga berporos dengan struktur organisasi dari sana. Hanya saja diberikan kewenangan untuk mengatur sesuai kebutuhan perusahaan. Secara umum terdapat delapan bagian/kelompok besar pada susunan di perusahaan PT Caterpillar Indonesia ini, yaitu:

a. Operation terbagi menjadi beberapa bagian yaitu fabrikasi, assembly, washing, painting dan maintenance, juga terbagi menjadi empat value stream: VS TSK Fabrikasi, VS HEX Fabrikasi, TSK Assembly, HEX Assembly.

b. Purchasing, Supply Chain dan GSND yang terdiri dari: Global Purchasing, Supply Chain, Scheduler, Global Logistic dan Transportation.

c. Business dan Human Resource yang terdiri dari: Personalia, Accounting, Finance, dan Training.

d. Technical Service yang terdiri dari: Enginering, Produk Engineer, Proses Enginer, Informasi Technology (IT).

e. Master Black Belt yang terdiri dari: Black Belt. 
f. Environmental, Health, and Safety (EHS) yang terdiri dari: Safety and Security, dan EHS.

\section{b. Hasil Analisa Data}

Berdasar data yang diperoleh menunjukkan bahwa pada bulan pertama dilakukan shipment dengan metode LCL sebanyak 25 kali dan metode konsolidasi sebanyak 19 kali, bulan kedua melakukan shipment untuk LCL sebanyak 23 kali dan konsolidasi sebanyak 29 kali, bulan ketiga melakukan shipment untuk LCL sebanyak 23 kali dan konsolidasi sebanyak 38 kali, bulan keempat melakukan shipment untuk LCL 85 sebanyak 29 kali dan konsolidasi sebanyak 38 kali, bulan kelima melakukan shipment LCL sebanyak 19 kali dan konsolidasi sebanyak 47 kali, bulan keenam melakukan shipment LCL sebanyak 20 kali dan konsolidasi sebanyak 52 kali, bulan ketujuh melakukan shipment LCL sebanyak 15 kali dan konsolidasi sebanyak 38 kali, bulan kedelapan melakukan shipment LCL sebanyak 29 kali dan konsolidasi sebanyak 60 kali, bulan kesembilan melakukan shipment LCL sebanyak 18 kali dan konsolidasi sebanyak 47 kali, bulan kesepuluh melakukan shipment LCL sebanyak 33 kali dan konsolidasi sebanyak 72 kali, bulan kesebelas melakukan shipment LCL sebanyak 11 kali dan konsolidasi sebanyak 46 kali, dan pada bulan kedua belas melakukan shipment LCL sebanyak 20 kali dan konsolidasi sebanyak 26 kali. Dalam setiap melakukan shipment terdapat jumlah kontainer yang berbeda-beda sehingga mempengaruhi total biaya setiap shipmentnya. Artinya, shipment menggunakan metode konsolidasi setiap bulannya lebih tinggi dari pada metode LCL, kecuali pada bulan pertama selama tahun 2014 karena ada proses transisi dari metode LCL ke metode konsolidasi.

Storage atau biaya penumpukan adalah jasa penyimpanan barang impor, pada saat barang turun dari kapal dan sudah melalui proses bea cukai (sudah keluar dari kawasan pelabuhan), tetapi gudang importir belum siap untuk menampung barang tersebut sehingga dilakukan penumpukan di gudang shipping line. Berdasar data yang diperoleh menunjukkan bahwa pada bulan pertama biaya storage LCL sebesar Rp 84,632.00, biaya storage konsolidasi sebesar Rp $38,206.00$, average biaya storage LCL sebesar Rp 3,385.28, average biaya storage konsolidasi sebesar $\mathrm{Rp}$ 2,010.84, dengan distance $\mathrm{Rp} \quad 1,374.44$ sehingga terjadi efisiensi sebesar $40.6 \%$, bulan kedua biaya storage LCL sebesar Rp 98,590.00, biaya 88 storage konsolidasi sebesar Rp 118,017.00, average biaya storage LCL sebesar Rp 4,286.25, average biaya storage konsolidasi sebesar Rp 4,069.55, dengan distance Rp 216,97 sehingga terjadi efisiensi sebesar $5.1 \%$, bulan ketiga biaya storage LCL sebesar Rp 75,557.00, biaya storage konsolidasi sebesar Rp 32,237.00, average biaya storage LCL sebesar Rp 3,285.09, biaya storage konsolidasi sebesar $\mathrm{Rp}$ 848.34, dengan distance $\mathrm{Rp} 2,436.74$ sehingga terjadi efisiensi sebesar $74.2 \%$, bulan keempat biaya storage LCL sebesar Rp 133,661.00, biaya storage konsolidasi sebesar Rp 130,093.00, average biaya storage LCL 4,609.55, average biaya storage konsolidasi sebesar Rp 3,423.50, dengan distance $\mathrm{Rp} 1,185,50$ sehingga terjadi efisiensi sebesar $25,7 \%$, bulan kelima biaya storage LCL sebesar Rp $58,155.00$, biaya storage konsolidasi sebesar 104,283.00, average biaya storage LCL sebesar Rp 3,060.79, average biaya storage konsolidasi sebesar $\mathrm{Rp} 2,218.79$, dengan distance $\mathrm{Rp} 842,00$ sehingga terjadi efisiensi sebesar $27,5 \%$, bulan keenam biaya storage LCL sebesar Rp 69,393.00, biaya storage konsolidasi sebesar $\mathrm{Rp} 95,249.00$, average biaya storage LCL sebesar Rp 3,469.65, average biaya storage konsolidasi sebesar Rp 1,831.71, dengan distance $\mathrm{Rp}$ 1,637.94 sehingga terjadi efisiensi sebesar Rp 47.2\%.

Selanjutnya bulan ketujuh biaya storage LCL sebesar Rp 58,126.00, biaya storage konsolidasi sebesar $\mathrm{Rp} 111,581.00$, average biaya storage LCL sebesar Rp 3,875.07, average biaya storage konsolidasi sebesar Rp 2,936.34, dengan distance $\mathrm{Rp} 938.72$ sehingga terjadi efisiensi sebesar 24,2\%, 
Achsanul Nashir, Analisis Efisiensi Biaya Perbandingan Metode LCL Dan Konsolidasi...

bulan kedelapan biaya 89 storage LCL sebesar Rp 154,198.00, biaya storage konsolidasi sebesar Rp 182,611.00, average biaya storage LCL sebesar Rp 5,317.17, average biaya storage konsolidasi $\mathrm{Rp}$ 3,043.52, dengan distance $\mathrm{Rp} 2,273.66$ sehingga terjadi efisiensi sebesar 42,7\%, bulan kesembilan biaya storage LCL sebesar Rp 52,537.00, biaya storage konsolidasi sebesar Rp 50,888.00, average biaya storage LCL sebesar Rp 2,918.72, average biaya storage konsolidasi sebesar Rp 1,082.72, dengan distance Rp 1,836,00 sehingga terjadi efisiensi sebesar 62,9\%, bulan kesepuluh biaya storage LCL sebesar Rp 127,205.00, biaya storage konsolidasi sebesar $\mathrm{Rp}$ 140,075.00, average biaya storage LCL sebesar Rp 3,854.70, average biaya storage konsolidasi sebesar Rp 1,945.49, dengan distance 1,909.21 sehingga terjadi efisiensi sebesar $49.5 \%$, bulan kesebelas biaya storage LCL sebesar Rp 18,818.00, biaya storage konsolidasi sebesar $\mathrm{Rp}$ 60,369.00, average biaya storage LCL sebesar Rp 1,710.73, average biaya storage konsolidasi sebesar $\mathrm{Rp}$ 1,312.37, dengan distance 398.36 sehingga terjadi efisiensi sebesar $23,3 \%$, dan pada bulan ke duabelas biaya storage LCL sebesar 65,485.00, biaya storage konsolidasi sebesar Rp 32,983.00, average biaya storage LCL sebesar Rp 3,274.25, average biaya storage konsolidasi sebesar Rp 1,268.58, dengan distance $\mathrm{Rp}$ 2,005.67 sehingga terjadi efisiensi sebesar 61,3\%. Ditemukan bahwa pada bulan ketiga terjadi nilai distance yang tinggi karena adanya peningkatan jumlah pengiriman dengan konsolidasi 90 sebanyak 38 pengiriman dengan biaya storage sebesar Rp.32,237.00 berbanding dengan LCL yang hanya 23 pengiriman tetapi biaya storage sebesar Rp 75,557.00 sehingga efisiensi yang didapat sebesar $74.2 \%$, dan pada bulan kedua terjadi nilai distance yang lebih rendah dengan efisiensi sebesar $5.1 \%$.

Kemudian biaya trucking adalah biaya pengambilan container dari Pelabuhan dan dikirim ke gudang importir atau gudang berikat sesuai permintaan dari pihak importer dan biaya yang dibebankan ke pihak importer sesuai jarak atau berdasarkan kesepakatan antara pihak transporter dengan pihak importir. Berdasar data yang diperoleh menunjukkan bahwa pada bulan pertama biaya trucking LCL sebesar Rp 65,450, biaya trucking konsolidasi sebesar Rp 28,545, average trucking LCL sebesar Rp 2,618, average trucking konsolidasi sebesar $\mathrm{Rp}$ 1,502, dengan distance $\mathrm{Rp} 1,116$ sehingga terjadi efisiensi sebesar $42.61 \%$, bulan kedua biaya trucking LCL sebesar Rp 38,539, biaya trucking konsolidasi sebesar Rp 45,765, average trucking LCL sebesar Rp 1,676, average trucking konsolidasi sebesar Rp 1,578, dengan distance Rp 98 sehingga terjadi efisiensi sebesar $5.82 \%$, bulan ketiga biaya trucking LCL sebesar Rp 48,132, biaya trucking konsolidasi sebesar Rp 64,680, average trucking LCL sebesar Rp 2,093, average trucking konsolidasi sebesar Rp 1,702, dengan distance Rp391 sehingga terjadi efisiensi sebesar $18.66 \%$, bulan keempat biaya trucking LCL sebesar Rp 71,565, biaya trucking konsolidasi sebesar Rp 66,330, average trucking LCL sebesar Rp 2,468, average trucking konsolidasi sebesar Rp 1,746, dengan distance Rp 722 sehinga terjadi efisiensi sebesar29.27\%, bulan kelima biaya trucking LCL sebesar Rp 52,407, biaya trucking konsolidasi sebesar Rp 84,645, average trucking LCL sebesar Rp 2,758, average trucking konsolidasi sebesar Rp 1,801, dengan distance Rp 957 sehingga terjadi efisiensi sebesar $34.71 \%$, bulan keenam biaya trucking LCL sebesar Rp 55,915, biaya trucking konsolidasi sebesar Rp 90,035, average trucking LCL sebesar Rp 2,796, average trucking konsolidasi sebesar Rp 1,731, dengan distance Rp 1064 sehingga terjadi efisiensi sebesar 38.07\%.

Lalu bulan ketujuh biaya trucking 93 LCL sebesar $\mathrm{Rp}$ 31,954, biaya trucking konsolidasi sebesar $\operatorname{Rp}$ 67,430, average trucking LCL sebesar Rp 2,130, average trucking konsolidasi sebesar Rp 1,774, dengan distance $\mathrm{Rp} 356$ sehingga terjadi efisiensi sebesar $16.70 \%$, bulan kedelapan biaya trucking LCL sebesar Rp 67,941, biaya trucking konsolidasi sebesar Rp 107,250, average trucking LCL sebesar Rp 2,343, average trucking konsolidasi sebesar $\mathrm{Rp}$ 1,788, dengan distance Rp 355 sehingga terjadi efisiensi sebesar $23.70 \%$. bulan 
kesembilan biaya trucking LCL sebesar Rp 49,825, biaya trucking konsolidasi sebesar $\mathrm{Rp}$ 87,855, average trucking LCL sebesar Rp 2,768, average trucking konsolidasi sebesar $\mathrm{Rp} 1,870$, dengan distance $\mathrm{Rp} 898$ sehingga terjadi efisiensi sebesar $32.45 \%$, bulan kesepuluh biaya trucking LCL sebesar Rp 85,976 , biaya trucking konsolidasi sebesar $\mathrm{Rp}$ 181,585 , average trucking LCL sebesar Rp 2,605, average trucking konsolidasi sebesar Rp 1,966, dengan distance Rp 639 sehingga terjadi efisiensi sebesar $24.54 \%$. bulan kesebelas biaya trucking LCL sebesar $\mathrm{Rp}$ 22,162, biaya trucking konsolidasi sebesar $\mathrm{Rp}$ 89,489, average trucking LCL Rp 2,015, average trucking konsolidasi sebesar $\mathrm{Rp}$ 1,945, dengan distance Rp 69 sehingga terjadi efisiensi sebesar $3.44 \%$, dan bulan kedua belas biaya trucking LCL sebesar Rp 53,642, biaya trucking konsolidasi sebesar $\mathrm{Rp} 56,890$, average trucking LCL sebesar Rp 2,682, average trucking konsolidasi sebesar Rp 2,188, dengan distance $\mathrm{Rp} 944$ sehingga terjadi efisiensi sebesar $18.42 \%$. Penjelasan lebih lanjut bahwa biaya trucking menggunakan metode konsolidasi setiap bulan lebih tinggi dari pada metode LCL seperti selama 2014.

Adapun biaya inland atau inland freight adalah semua biaya yang dibebankan kepada importir termasuk didalamnya biaya terminal atau 95 THC, gudang, LoLo, clearance, jasa PBM, pada saat barang turun dari kapal dan proses bea cukai (dalam kawasan pelabuhan ). Berdasar data yang diperoleh menunjukkan bahwa pada bulan pertama biaya freight LCL sebesar Rp 30,451, biaya freight konsolidasi sebesar Rp 108,925, average freight LCL sebesar Rp 7,613, average freight konsolidasi sebesar Rp 5,733, dengan distance sebesar Rp 1,880 sehingga terjadi efisiensi sebesar $24.69 \%$. bulan kedua biaya freight LCL sebesar Rp 46,369, biaya freight konsolidasi sebesar Rp 96 201,637, average freight LCL sebesar Rp 9,274, average freight konsolidasi sebesar Rp 6,953, dengan distance Rp 2,321 sehingga terjadi efisiensi sebesar $25.03 \%$. bulan ketiga biaya freight LCL sebesar Rp 59,713 , biaya freight konsolidasi sebesar $R p$
336,273, average freight LCL sebesar Rp 11,943 , average freight konsolidasi sebesar Rp 8,848, dengan distance Rp 3,094 sehingga terjadi efisiensi sebesar $25.91 \%$, bulan keempat biaya freight LCL sebesar Rp 53,013, biaya freight konsolidasi sebesar Rp 271,712, average freight LCL sebesar Rp 6,627, average freight konsolidasi sebesar $\mathrm{Rp}$ 7,150, dengan distance (Rp 524) sehingga terjadi non efisiensi sebesar $-7.90 \%$, bulan kelima biaya freight LCL sebesar Rp 18,044, biaya freight konsolidasi sebesar Rp 309,825, average freight LCL sebesar Rp 6,015, average freight konsolidasi sebesar Rp 6,592, dengan distance ( $R p$ 577) sehingga terjadi non efisiensi sebesar $9.60 \%$.

Pada bulan keenam biaya freight LCL sebesar Rp 30,197, biaya freight konsolidasi sebesar Rp 384,647, average freight LCL sebesar Rp 6,039, average freight konsolidasi sebesar $\operatorname{Rp} 7,397$, dengan distance $(\operatorname{Rp} 1,358)$ sehingga terjadi non efisiensi sebesar $22.48 \%$, bulan ketujuh biaya freight LCL sebesar Rp 52,306 , biaya freight konsolidasi sebesar Rp 325,154 , average freight LCL sebesar Rp 8,718 , average freight konsolidasi sebesar Rp 8,557, dengan distance Rp 161 sehingga terjadi efisiensi sebesar $1.85 \%$, bulan kedelapan biaya freight LCL sebesar Rp 154,379 , biaya freight konsolidasi sebesar Rp 515,348, average freight LCL sebesar Rp 9,081, average freight konsolidasi 97 sebesar Rp 8,589, dengan distance Rp 492 sehingga terjadi efisiensi sebesar $5.42 \%$, bulan kesembilan biaya freight LCL sebesar Rp 75,478 , biaya freight konsolidasi sebesar Rp 418,717, average freight LCL sebesar Rp 9,435, average freight konsolidasi sebesar Rp 8,909, dengan distance RP 526 sehingga terjadi efisiensi biaya sebesar $5.57 \%$, bulan kesepuluh biaya freight LCL sebesar Rp 97,511, biaya freight konsolidasi sebesar Rp 483,260 , average freight LCL sebesar Rp 6,965, average freight konsolidasi sebesar Rp 6712, dengan distance Rp 253 sehingga terjadi efisiensi sebesar $3.63 \%$, bulan kesebelas biaya freight LCL sebesar Rp 18,142 , biaya freight konsolidasi sebesar $\mathrm{Rp}$ 287,384, average freight LCL sebesar Rp 
4,536, average freight konsolidasi sebesar Rp 6,247, dengan distance (Rp1,712) sehingga terjadi non efisiensi sebesar $37.75 \%$, pada bulan kedua belas biaya freight LCL sebesar Rp 44,789, biaya freight konsolidasi sebesar Rp 205,380, average freight LCL sebesar Rp 7,465, average freight konsolidasi sebesar $\mathrm{Rp}$ 7,899, dengan distance ( $\mathrm{Rp}$ 434) sehingga terjadi non efisiensi sebesar $5.82 \%$. Untuk penjelasan lebih lanjut menunjukkan bahwa shipment menggunakan metode konsolidasi setiap bulannya sangat bervariasi karena pada bulan keempat, lima, enam dan kesebelas lebih tinggi sedangkan konsolidasi lebih rendah pada bulan pertama, kedua, ketiga, kedelapan, kesembilan ,dan kesepuluh dari metode LCL di selama 2014.

Untuk mendapatkan nilai efisiensi atas semua biaya Storage, Trucking dan Freight maka pada bulan pertama biaya LCL sebesar Rp 60,178, biaya konsolidasi sebesar Rp 58,559, average LCL sebesar $\mathrm{Rp}$ 4,539, average konsolidasi sebesar Rp 3,082, dengan distance $\mathrm{Rp}$ 1,456.64 sehingga didapat efisiensi sebesar Rp 32.09\%. bulan kedua biaya LCL sebesar Rp 61,166, biaya konsolidasi sebesar Rp 121,806, average LCL sebesar Rp 5,079, average konsolidasi sebesar Rp 4,200, dengan distance Rp 878 sehingga didapatkan efisiensi sebesar $17.30 \%$. bulan ketiga biaya LCL sebesar Rp 61,134, biaya konsolidasi sebesar Rp 144,385, average LCL sebesar Rp 5,773, average konsolidasi sebesar Rp 3,800, dengan distance Rp 1,974 sehingga didapatkan efisiensi sebesar $34.19 \%$, bulan keempat biaya LCL sebesar Rp 86,080, biaya konsolidasi sebesar Rp 156,045, average LCL sebesar Rp 4,568, average konsolidasi sebesar Rp 4,106, dengan 100 distance 461 sehingga didapatkan efisiensi sebesar $10.10 \%$, bulan kelima biaya LCL sebesar Rp 42,869, biaya konsolidasi sebesar Rp 166,251, average LCL sebesar Rp 3,945, average konsolidasi sebesar Rp 3,537, dengan distance 407 sehingga didapatkan efisiensi sebesar $10.33 \%$, bulan keenam baiaya LCL sebesar Rp 51,835, biaya konsolidasi sebesar Rp 189,977, average LCL sebesar Rp 4,102, average konsolidasi sebesar $\mathrm{Rp} 3,653$, dengan distance $\mathrm{Rp} 448.20$ sehingga didapatkan efisiensi sebesar $10.93 \%$, bulan ketujuh biaya LCL sebesar Rp 47,462, biaya konsolidasi sebesar Rp 168,055, average LCL sebesar Rp 4,908, average konsolidasi sebesar $\mathrm{Rp} 4,423$, dengan distance $\mathrm{Rp} 485.17$ sehingga didapatkan efisiensi sebesar $9.89 \%$.

Selanjutnya bulan kedelapan biaya LCL sebesar Rp 125,506, biaya konsolidasi sebesar Rp 268,403, average LCL sebesar Rp 5,580, average konsolidasi sebesar Rp 4,473, dengan distance $\mathrm{Rp} 1,107$ sehingga didapatkan efisiensi sebesar $19.84 \%$, bulan kesembilan biaya LCL sebesar Rp 59,280, biaya konsolidasi sebesar Rp 185,830, average LCL sebesar Rp 5,041, average konsolidasi sebesar $\mathrm{Rp}$ 3,954, dengan distance $\mathrm{Rp} 1086.68$ sehingga didapatkan efisiensi sebesar $21.56 \%$, bulan kesepuluh biaya LCL sebesar Rp 103,564, biaya konsolidasi sebesar Rp 254,962, average LCL sebesar Rp 4,475, average konsolidasi sebesar Rp 3,541, dengan distance Rp 934 sehingga didapatkan efisiensi sebesar $20.87 \%$, bulan kesebelas biaya LCL sebesar Rp 19,707, biaya konsolidasi sebesar Rp 145,747, average LCL sebesar Rp 2,754, average konsolidasi sebesar Rp 3,168, dengan distance (Rp 101 415) sehingga didapatkan non efisiensi sebesar $-15.06 \%$, bulan kedua belas biaya LCL sebesar Rp 54,639, biaya konsolidasi sebesar Rp 98,418, average LCL sebesar Rp 4,474, average konsolidasi sebesar $\mathrm{Rp}$ 3,785, dengan distance $\mathrm{Rp} 688.43$ sehingga didapatkan efisiensi sebesar $15.39 \%$ Untuk penjelasan lebih lanjut bahwa biaya average menggunakan metode LCL setiap bulannya lebih tinggi dari pada metode konsolidasi, kecuali pada bulan kesebelas selama 2014.

\section{c. Analisis dan Interpretasi Penelitian}

Untuk membuktikan bahwa kedua metode LCL dan konsolidasi memiliki perbedaan yang signifikan dalam hal efisiensi biaya maka perlu dilakukan analisis lebih lanjut berdasarkan data yang ada pada masing masing indicator shipment yang diteliti. Untuk menganalisis data storage yang digunakan uji t yaitu Paired Sample T-Test dengan aplikasi SPSS dihasilkan tabel Storage LCL memiliki rata-rata sebesar 3587.33 dengan deviasi 912.94 sedangkan untuk storage konsolidasi memiliki rata-rata 
2166.08 dengan deviasi 1009.17 standar deviasi. Kemudian analisis hubungan biaya storage antara metode LCL dengan metode konsolidasi berdasarkan SPSS menghasilkan korelasi antara storage LCL dan konsolidasi diperoleh sebesar 0.725 dengan nilai signifikansi 0.008 atau lebih kecil dari 0.05, dengan demikian antara LCL dan Konsolidasi ada korelasi yang kuat. Selanjutnya tabel analisa di atas, dengan menggunakan taraf signifikansi 0.05 diperoleh bahwa Thitung $=$ $6.853>$ Ttabel $=1,96$ dan $\alpha$ hitung $(0.000)<$ 0.05 dengan demikian $\mathrm{H} 0$ ditolak dan $\mathrm{H} 1$ diterima. Artinya bahwa Ada perbedaan yang signifikan efisiensi biaya rata-rata storage antara metode konsolidasi dengan LCL.

Kemudian analisis data trucking yang menggunakan uji $\mathrm{t}$ juga diperoleh Trucking LCL memiliki rata-rata sebesar 2412.67 dengan deviasi 361.18 sedangkan untuk Trucking FCL 1799.25 dengan deviasi 180.95 standar deviasi. Hasil korelasi antara trucking LCL dengan Konsolidasi diperoleh sebesar 0.301 dengan nilai signifikansi 0.342. Dengan demikian antara LCL dan Konsolidasi tidak terkorelasi secara nyata, karena signifikansi lebih besar dari 0.05. Selanjutnya untuk menganalisis, apakah ada perbedaan yang signifikan tingkat efisiensi biaya trucking antara metode LCL dengan konsolidasi maka berdasarkan hasil olah data dengan SPSS diperoleh hasil dengan menggunakan taraf signifikansi 0.05 diperoleh bahwa Thitung $=$ $6.038>$ Ttabel $=1,96$ dan $\alpha$ hitung $(0.000)<$ 0.05 dengan demikian $\mathrm{H} 0$ ditolak dan $\mathrm{H} 1$ diterima. Artinya bahwa ada perbedaan yang signifikan efisiensi biaya rata-rata trucking antara metode konsolidasi dengan LCL.

Analisis data freight yang digunakan uji $\mathrm{t}$ yaitu Paired Sample T-Test dengan aplikasi SPSS menghasilkan rata-rata sebesar 7809.67 dengan deviasi 1992.10 sedangkan untuk freight konsolidasi memiliki rata-rata 7465.58 dengan deviasi 1079.55 standar deviasi. Kemudian analisis hubungan biaya freight antara metode LCL dengan metode konsolidasi berdasarkan SPSS diperoleh hasil korelasi antara freight LCL dengan konsolidasi diperoleh sebesar 0.702 dengan nilai signifikansi 0.11. Dengan demikian antara LCL dan konsolidasi tidak terkorelasi secara nyata, karena signifikansi lebih besar dari 0,05 . Selanjutnya untuk menganalisis, apakah ada perbedaan yang signifikan tingkat efisiensi biaya freight antara metode LCL dengan konsolidasi maka berdasarkan hasil olah data dengan SPSS diperoleh hasil dengan menggunakan taraf signifikansi 0.05 diperoleh bahwa Thitung $=0.8180 .05$ dengan demikian $\mathrm{H} 0$ diterima dan $\mathrm{H} 1$ ditolak. Artinya bahwa tidak ada perbedaan efisiensi biaya rata-rata freight antara metode konsolidasi dengan LCL.

Untuk menganalisis data average dengan uji $\mathrm{t}$ aplikasi SPSS juga maka LCL memiliki rata-rata sebesar 4603.16 dengan deviasi 796.35 sedangkan untuk FCL memiliki ratarata 3810.16 dengan deviasi 446.21 standar deviasi. Kemudian analisis hubungan biaya LCL antara metode LCL dengan metode konsolidasi berdasarkan SPSS diperoleh hasil korelasi antara average LCL dengan konsolidasi diperoleh sebesar 0.663 dengan nilai signifikansi 0.19. Dengan demikian antara LCL dan konsolidasi tidak terkorelasi secara nyata, karena signifikansi lebih besar dari 0,05 . Selanjutnya untuk menganalisis, apakah ada perbedaan yang signifikan tingkat efisiensi biaya trucking antara metode LCL dengan konsolidasi maka berdasarkan hasil olah data dengan SPSS dengan menggunakan taraf signifikansi 0.05 diperoleh bahwa Thitung $=4.564>$ Ttabel $=1,96$ dan $\alpha$ hitung $(0.01)<0.05$ dengan demikian H0 ditolak dan H1 diterima. Artinya bahwa ada perbedaan yang signifikan efisiensi biaya rata-rata keseluruhan antara metode konsolidasi dengan LCL.

\section{d. Pembahasan}

Jumlah shipment yang masuk pada bulan pertama tahun 2014 dengan metode LCL sebanyak 25 kali sedangkan dengan metode konsolidasi hanya 19 kali , hal ini karena pada bulan tersebut terjadi transisi dari metode LCL menuju metode konsolidasi. Kemudian pada bulan kesebelas menuju bulan kedua belas terjadi penurunan pada shipment yang 
menggunakan konsolidasi sedangkan pada metode LCL mengalami kenaikan, hal ini terjadi karena pada akhir tahun banyak hari libur yang mempengaruhi pengiriman menggunakan konsolidasi. Untuk mengetahui perbandingan biaya pengiriman menggunakan metode LCL dan konsolidasi diukur berdasarkan tiga indikator utama yang berpengaruh antara lain Storage, Trucking dan Freight.

Berdasarkan biaya storage didapatkan efisiensi sebesar $40.35 \%$ pada penggunaan metode konsolidasi dibanding dengan metode LCL dengan rata-rata biaya per shipment sebesar Rp 2,165.98 pada metode konsolidasi dan Rp 3,587.25 pada metode LCL. Dan efisiensi biaya tertinggi pada bulan ketiga sebesar $74.2 \%$ dan terendah pada bulan kedua sebesar $5.1 \%$, hal ini terjadi karena adanya penumpukan pada bulan ketiga untuk metode konsolidasi. Selanjutnya berdasarkan pengujian statistic dengan uji $\mathrm{t}$ diperoleh bahwa Thitung $=6.853>$ Ttabel $=1,96$ dan $\alpha$ hitung $(0.000)<0.05$ sehingga kriteria tersebut menolak $\mathrm{H} 0$ dan menerima $\mathrm{H} 1$, artinya bahwa rata-rata biaya storage untuk metode LCL dengan metode konsolidasi ada perbedaan yang signifikan, dengan demikian terjadi efisiensi yang nyata pada metode konsolidasi terhadap metode LCL sehingga metode konsolidasi layak diterapkan pada proses storage.

Berdasarkan biaya trucking didapatkan efisiensi sebesar $24.0 \%$ pada penggunaan metode konsolidasi dibanding dengan metode LCL dengan rata-rata biaya per shipment sebesar Rp 1,799 pada metode konsolidasi dan Rp 2,413 pada metode LCL. Dan efisiensi biaya tertinggi pada bulan keenam sebesar $38.072 \%$ dan terendah pada bulan kesebelas sebesar $3.44 \%$, hal ini terjadi karena adanya penambahan jumlah pengiriman dengan kontainer pada bulan keenam untuk metode konsolidasi. Selanjutnya berdasarkan pengujian statistic dengan uji $\mathrm{t}$ diperoleh bahwa Thitung $=6.038>$ Ttabel $=1,96$ dan $\alpha$ hitung $(0.000)<0.05$ sehingga kriteria tersebut menolak $\mathrm{H} 0$ dan menerima $\mathrm{H} 1$, artinya bahwa rata-rata biaya trucking untuk metode LCL dengan metode konsolidasi ada perbedaan yang signifikan, dengan demikian terjadi efisiensi yang nyata pada metode konsolidasi terhadap metode LCL sehingga metode konsolidasi layak diterapkan pada proses trucking.

Berdasarkan biaya freight didapatkan nilai sebesar $0.71 \%$ pada penggunaan metode konsolidasi dibanding dengan metode LCL dengan rata-rata biaya per shipment sebesar Rp 7,466 pada metode konsolidasi dan Rp 7,809 pada metode LCL. Dan efisiensi biaya tertinggi pada bulan ketiga sebesar $25.91 \%$ dan terendah pada bulan kesebelas sebesar $37.75 \%$, hal ini terjadi karena adanya perubahan jadwal kedatangan barang pada bulan ketiga untuk metode konsolidasi. Selanjutnya berdasarkan pengujian statistic dengan uji t diperoleh bahwa Thitung $=0.818$ 0.05 sehingga kriteria tersebut menerima $\mathrm{HO}$ dan menolak $\mathrm{H} 1$, artinya bahwa rata-rata biaya freight untuk metode LCL dengan metode konsolidasi tidak ada perbedaan yang signifikan.

Berdasarkan biaya average (rata-rata ) didapatkan efisiensi sebesar $15.62 \%$ pada penggunaan metode konsolidasi dibanding dengan metode LCL dengan rata-rata biaya per shipment sebesar Rp 3,810 pada metode konsolidasi dan Rp 4,603 pada metode LCL. Dan efisiensi biaya tertinggi pada bulan ketiga sebesar $34.19 \%$ dan terendah pada bulan kesebelas sebesar $-15.06 \%$, hal ini menjadi indikasi adanya kesamaan pada efisiensi biaya storage dan trucking untuk metode konsolidasi. Selanjutnya berdasarkan pengujian statistic dengan uji $\mathrm{t}$ diperoleh bahwa Thitung $=4.564>$ Ttabel $=1,96$ dan $\alpha$ hitung $(0.01)<0.05$ sehingga kriteria tersebut menolak H0 dan menerima H1, artinya bahwa rata-rata biaya keseluruhan untuk metode LCL dengan metode konsolidasi ada perbedaan yang signifikan, dengan demikian terjadi efisiensi yang nyata pada metode konsolidasi terhadap metode LCL sehingga metode konsolidasi layak diterapkan pada proses impor komponen PT Caterpillar Indonesia.

\section{SIMPULAN DAN SARAN}

Berdasarkan hasil pengolahan data yang dilakukan, maka dapat disimpulkan bahwa analisis efisiensi biaya perbandingan metode 
LCL dan konsolidasi pada proses impor komponen PT Caterpillar Indonesia dari China dan Jepang telah dilaksanakan dengan cukup baik. Hal ini didukung oleh hasil analisis data, sebagai berikut:

1. Ada perbedaan efisiensi biaya rata-rata storage antara metode konsolidasi dengan metode LCL. Biaya rata-rata storage metode konsolidasi lebih efisien sebesar $40.35 \%$ dibandingkan biaya rata-rata storage pada metode LCL.

2. Ada perbedaan efisiensi biaya rata-rata trucking antara metode konsolidasi dengan metode LCL. Biaya rata-rata trucking metode konsolidasi lebih efisien sebesar $24 \%$ dibandingkan biaya rata-rata trucking pada metode LCL.

3. Tidak ada perbedaan efisiensi biaya ratarata freight antara metode konsolidasi dengan metode LCL. Biaya rata-rata freight metode konsolidasi sama saja dengan biaya rata-rata freight pada metode LCL.

4. Ada perbedaan efisiensi biaya rata-rata keseluruhan antara metode konsolidasi dengan metode LCL. Biaya rata-rata keseluruhan metode konsolidasi lebih efisien sebesar $15.62 \%$ dibandingkan biaya rata-rata trucking pada metode LCL.

Adapun saran yang diberikan adalah:

1. Diharapkan pimpinan dapat memaksimalkan untuk proses impor komponen dari China dan Jepang dengan metode konsolidasi agar efisiensi biaya pada Storage dan trucking dapat lebih meningkat ke depannya.

2. Perlunya menganalisa lebih lanjut untuk mencari efisiensi biaya Freight metode konsolidasi sehingga lebih baik lagi pada tahun yang akan datang. 3 .

3. Diharapkan pimpinan meningkatkan efektivitas penerapan metode konsolidasi untuk Storage, Trucking dan Freight.

Dengan demikian diharapkan efisiensi biaya yang diharapkan berhasil dan seluruh karyawan lebih memperhatikan pelaksanaan tugas dan tanggung jawab sesuai dengan tugas dan fungsinya masing-masing. Dalam hal ini juga diharapkan peran serta dari pimpinan untuk membimbing, mengarahkan dan mengefektifkan karyawan agar bekerja lebih bertanggung jawab.

\section{DAFTAR PUSTAKA}

Assauri. (2004). Manajemen Produksi dan Operasi. Jakarta: Lembaga Fakultas Ekonomi UI.

Badri, Sofwan. (2008). Konsep-Konsep Dasar Administrasi, Administrasi Negara dan Administrasi Pembangunan. Jakarta: PT. Bina Aksara.

Burtis M., (2010). A. Ramadhan Siregar. Perilaku Terhadap Persaingan Usaha. Jakarta: PT Penerbit IPB Press.

Elhauge E, Geraldin D. (2007). A. Ramadhan Siregar. Perilaku Terhadap Persaingan Usaha. Jakarta: PT Penerbit IPB Press.

Gibson. (2012). Manajemen. Jilid Pertama. Jakarta: PT. Prenhalindo,

Gie, The Liang. (2006). Administrasi Perkantoran. Yogyakarta: Liberty.

Handayaningrat, Soewarno. (2008). Pengantar Studi Ilmu Administrasi dan Manajemen. Jakarta: PT. Gunung Agung.

Keban. (2004). Enam Dimensi Strategis Administrasi Publik, Konsep Teori dan Isu. Yogyakarta: Gaya Media.

Lipczynski, J Wilson. (2001). A. Ramadhan Siregar. Perilaku Terhadap Persaingan Usaha. Jakarta: PT Penerbit IPB Press.

Noh SS. (2009). A. Ramadhan Siregar. Perilaku Terhadap Persaingan Usaha. Jakarta: PT Penerbit IPB Press.

Sedarmayanti, (2009). Sumber Daya Manusia dan Produktivitas Kerja. Bandung: CV Mandiri Karya.

Siagian, S. P. (2006). Filsafat Administrasi. Jakarta: PT. Gunung Agung.

Suganda, Dann. (2001). Administrasi Strategi, Taktik dan Teknik Penciptaan Efisiensi. Jakarta: Intermedia.

Tangkilisan. (2007). Pengantar Administrasi Negara. Jakarta: Universitas Terbuka.

Westra. (2009). Efektivitas Organisasi. Jakarta: Erlangga.

Wibawa. (2009). Kebijakan Publik, Proses dan Analisis. Yogyakarta: Intermedia. 